MaPan : Jurnal Matematika dan Pembelajaran

p-ISSN: 2354-6883 ; e-ISSN: 2581-172X

Volume 4, Nomor 1, Juni 2016

\title{
STUDI KEMAMPUAN MAHASISWA MENDESAIN PERENCANAAN PEMBELAJARAN MATEMATIKA DI SEKOLAH MENENGAH PERTAMA BERBASIS PENDEKATAN SAINTIFIK
}

\author{
Nursalam ${ }^{1)}$, Muhammad Rusydi Rasyid ${ }^{2)}$ \\ 1,2Fakultas Tarbiyah dan Keguruan UIN Alauddin Makassar \\ 1,2Kampus II: Jalan H. M. Yasin Limpo Nomor 36 Samata-Gowa \\ E-mail: nursalam_ftk@uin-alauddin.ac.id ${ }^{1}$,
}

\begin{abstract}
Abstrak
Penelitian ini bertujuan untuk mengetahui kemampuan mahasiswa jurusan pendidikan matematika yang melakukan kegiatan Praktik Pengalaman Lapangan (PPL) dalam mendesain pembelajaran yang berbasis kurikulum 2013 khususnya dalam menyusun rencana pelaksanaan pembelajaran dengan pendekatan saintifik. Pendekatan penelitian yang digunakan adalah pendekatan kualitatif dengan melakukan analisis pada perangkat pembelajaran yang menggunakan kurikulum 2013 dengan menerapkan pendekatan saintifik yaitu mengamati, menanya, mencoba, menaar, dan mengomunikasikan hail yang digunakan oleh mahasiswa dalam melaksanaan PPL di Sekolah. Hasil penelitian menunjukkan bahwa mahasiswa PPL jurusan pendidikan matematika dalam menyusun skenario pembelajaran dengan pendekatan saintifik masih kurang khususnya pada aktivitas mengamati dan menanya. Oleh karenanya perlu pendampingan yang serius oleh guru pamong dan dosen pembimbing dalam mengarahkan mahasiswa PPL dalam menyusun skenario pembelajaran.
\end{abstract}

Kata Kunci: Perencanaan Pembelajaran, Kurikulum 2013, Pendekatan Saintifik

$\mathrm{B}$ elajar merupakan kegiatan yang paling pokok dalam suatu proses pendidikan khususnya pada pendidikan formal di sekolah. Berhasil tidaknya tujuan pendidikan dapat dilihat dari pencapaian kompetensi selama proses pembelajaran berlangsung. Belajar merupakan proses dasar dari perkembangan hidup manusia. Dengan belajar, manusia melakukan perubahan-perubahan kualitatif individu sehingga tingkah lakunya berkembang. Semua aktifitas dan prestasi hidup manusia tidak lain adalah hasil dari belajar (Eggen dan Kauchack, 1994). Belajar bukan sekadar menurut pengalaman, belajar adalah suatu proses. Karena itu belajar berlangsung 
secara aktif dan integrative dengan menggunakan berbagai bentuk perbuatan untuk mencapi suatu tujuan.

Proses pembelajaran memiliki dua paradigma yang berkembang, meskipun salah satunya adalah old fashion, yaitu teacher center dan student center (Joyce dan Weil, 1986). Kevin Barry dan Len King (2002) menulis seputar eksistensi pandangan teacher center yang sudah menjadi great paradigm dan berkembang di alam bawah sadar para guru dan siswa. Pandangan ini menjelaskan bahwa semua informasi, main resources-nya berasal dari guru. Guru yang menjadi nakoda dari lalu lintas semua informasi. Harapan agar siswa bisa melakukan critical analysis apalagi untuk berimprovisasi sangatlah jauh.

Siswa merasa segan bahkan tidak ada keinginan untuk menambah pengetahuan baru yang mungkin saja bisa diperoleh dari berbagai media, seperti: alam, informasi, atau sumber-sumber lain di sekitarnya yang 'mungkin' erat kaitannya dengan materi yang diterima di sekolahnya. Siswa akan menganggap dirinya 'kualat' jika ia berposisi lebih tahu atau mendapatkan informasi pengetahuan lebih dahulu dari 'sang guru'. Demikian pula, seorang guru sudah 'menikmati' dan pandangan tersebut, dia tidak mempunyai keinginan agar siswanya maju apalagi kalau dikatakan siswa tersebut lebih cerdas dari gurunya, karena hal itu adalah 'aib' di hadapan siswa dan di kalangan masyarakat umum. Ia akan merasa senang jika materinya dianggap sukar, hanya dia yang tahu dan hanya dia yang bisa mengajarkannya. Fenomena ini masih sering dijumpai di sekolah-sekolah tertentu (di beberpa sekolah terpencil yang minim informasi) terutama sekolah yang mana gurunya belum mampu mengakselerasikan kompetensi mengajarnya.

Sebaliknya, untuk student center, di antara fungsi utama seorang guru di dalam kelas adalah sebagai fasilitator. Guru lebih sering memandu siswa untuk melakukan aktivitas belajar sehingga informasi itu bisa berjalan dari dua arah, mungkin informasi itu dari guru dan mungkin juga informasi baru itu berasal dari siswa, sehingga benar-benar terjadi proses take and give (Good dan Brophy, 2003). Tidak hanya pengetahuan atau informasi guru bisa sama dengan siswanya, bahkan siswa tersebut bisa lebih dulu tahu dari gurunya. Karena perkembangan teknologi dan informasi yang sangat pesat sekarang, guru bukan lagi satu-satunya sumber belajar (learning resource). Seorang pengajar yang baik harus menyikapi hal ini secara positif. Pengajar harus berusaha cepat menyesuaikan diri dengan jalan mengakses informasi 
sebanyak-banyaknya serta selalu melakukan update informasi dan pengetahuan yang terkait dengan bidang dan keahliannya.

Sejalan dengan perubahan kurikulum dan desentralisasi pendidikan, maka bukan lagi eranya bagi seorang pengajar untuk selalu menunggu petunjuk dari atasan (kepala sekolah, pengawas, dan seterusnya). Ia harus proaktif mencari, berimprovisasi, dan melakukan inovasi baik pada saat merancang KBM maupun pada saat melakukan proses transformasi pengetahun di dalam kelas (Harmer, 1998). Seorang pengajar yang profesional selalu berusaha mencari cara yang terbaik untuk mencapai sasaran pembelajaran. Ia akan menggunakan berbagai macam metode dan strategi dalam rangka membantu siswa untuk mencerna materi pelajaran lebih cepat dan efisien. Dalam sistem pengajaran modern, keterlibatan guru mulai dari perencanaan, inovasi pendidikan sampai kepada pelaksanaan dan evaluasinya memainkan peran yang sangat besar bagi keberhasilan suatu pengajaran. Guru di sekolah mempunyai peran yang luas sebagai pen-didik, orangtua, teman, dokter, motivator, dan lain sebagainya.

Pada tataran operasionalnya, satu kondisi di lapangan sering dijumpai belum maksimalnya kegiatan pembelajaran yang berlangsung di setiap satuan pendidikan sehingga hasil yang dicapai juga belum optimal. Salah satu indikator untuk melihat hal tersebut adalah rendahnya prestasi belajar yang dicapai oleh siswa. Prestasi belajar yang dicapai siswa pada hakekatnya merupakan pencerminan dari usaha belajar. Pada umumnya semakin baik usaha belajar maka semakin baik pula prestasi yang dicapai. Tentunya hal ini tidak terlepas dari faktor-faktor yang mempengaruhinya.

Guru memberikan kemudahan untuk proses ini, dengan mengembangkan suasana belajar yang memberi kesempatan peserta didik untuk menemukan, menerapkan ide-ide mereka sendiri, dan secara sadar menggunakan strategi mereka sendiri untuk belajar. Guru mengembangkan kesempatan belajar kepada peserta didik untuk meniti anak tangga yang membawa peserta didik kepemahaman yang lebih tinggi, semula dilakukan dengan bantuan guru tetapi semakin lama semakin mandiri (Wright, 1987). Bagi peserta didik, pembelajaran harus bergeser dari "diberi tahu" menjadi "aktif mencari tahu."

Di dalam pembelajaran, peserta didik mengkonstruksi pengetahuan bagi dirinya. Bagi pesertadidik, pengetahuan yang dimilikinya bersifat dinamis, berkembang dari sederhana menuju kompleks, dari ruang lingkup dirinya dan di sekitarnya menuju ruang lingkup yang lebih luas, dan 
dariyangbersifat konkrit menuju abstrak. Sebagai manusia yang sedang berkembang, peserta didik telah, sedang, dan/atau akan mengalami empat tahap perkembangan intelektual, yakni sensori motor, pra-operasional, operasional konkrit, dan operasional formal. Secara umum jenjang pertam aterjadi sebelum seseorang memasuki usia sekolah, jejang kedua dan ketiga dimulai ketika seseorang menjadi peserta didik di jenjang pendidikan dasar, sedangkan jenjang keempat dimulai sejak tahun kelima dan keenam sekolah dasar.

Proses pembelajaran terjadi secara internal pada diri peserta didik. Proses tersebut mungkin saja terjadi akibat dari stimulus luar yang diberikan guru, teman, lingkungan. Proses tersebut mungkin pula terjadi akibat dari stimulus dalam diri peserta didik yang terutama disebabkan oleh rasa ingin tahu. Proses pembelajaran dapat pula terjadi sebagai gabungan dari stimulus luar dan dalam. Dalam proses pembelajaran, guru perlu mengembangkan kedua stimulus pada diri setiap peserta didik.

Di dalam pembelajaran, peserta didik difasilitasi untuk terlibat secara aktif mengembangkan potensi dirinya menjadi kompetensi. Guru menyediakan pengalaman belajar bagi peserta didik untuk melakukan berbagai kegiatan yang memungkinkan mereka mengembangkan potensi yang dimiliki mereka menjadi kompetensi yang ditetapkan dalam dokumen kurikulum atau lebih. Pengalaman belajar tersebut semakin lama semakin meningkat menjadi kebiasaan belajar mandiri dan ajeg sebagai salah satu dasar untuk belajar sepanjang hayat.

Dalam suatu kegiatan belajar dapat terjadi pengembangan sikap, pengetahuan, dan keterampilan dalam kombinasi dan penekanan yang bervariasi (Matsumo, 2000). Setiap kegiatan belajar memiliki kombinasi dan penekanan yang berbeda dari kegiatan belajar lain tergantung dari sifat muatan yang dipelajari. Meskipun demikian, pengetahuan selalu menjadi unsur penggerak untuk pengembangan kemampuan lain.

Strategi pembelajaran sangat diperlukan dalam menunjang terwujudnya seluruh kompetensi yang dimuat dalam Kurikulum 2013. Dalam arti bahwa kurikulum memuat apa yang seharusnya diajarkan kepada peserta didik, sedangkan pembelajaran merupakan cara bagaimana apa yang diajarkan bisa dikuasai oleh peserta didik. Pelaksanaan pembelajaran didahului dengan penyiapan rencana pelaksanaan pembelajaran (RPP) yang dikembangkan oleh guru baik secara individual maupun kelompok yang mengacu pada silabus. 
Perencanaan pembelajaran merupakan sebuah usaha untuk menjalankan proses pembelajaran agar dapat berjalan dengan baik dan matang sehingga akan mendapatkan hasil pembelajaran yang memuaskan seperti apa yang telah diharapkan. Perencanaan pembelajaran ini sangat penting menjadi pedoman bagi seorang tenaga pendidik agar mampu mengarahkan peserta didiknya untuk belajar dengan baik (Danim, 2002). Ada sebuah masalah pokok yang cukup pelik yang harus dihadapi dunia pendidikan yakni kehadiran teknologi yang selain memiliki dampak yang baik juga ada efek sampingnya bagi seorang peserta didik khususnya anakanak. Biasanya karena penyalahgunaan teknologi ini membuat proses pembelajaran pada seorang peserta didik menjadi terganggu sehingga jika terjadi hal ini seorang tenaga pendidik harus tanggap dan melakukan upaya yang tepat. Salah satunya adalah dengan melakukan perencanaan pembelajaran yang baik dan tepat agar proses pembelajaran yang terjadi tetap terkontrol dengan baik dan agar dapat menjawab tantangan perubahan teknologi terhadap peserta didik.

Secara ideal tujuan perencanaan pembelajaran adalah menguasai sepenuhnya bahan dan materi ajar, metode dan penggunaan alat dan perlengkapan pembelajaran, menyampaikan kurikulum atas dasar bahasan dan mengelola alokasi waktu yang tersedia dan membelajarkan siswa sesuai yang diprogramkan (Bluestein, 2013). Dengan demikian, tujuan perencanaan itu memungkinkan guru memilih metoda mana yang sesuai sehingga proses pembelajaran itu mengarah dan dapat mencapai tujuan yang telah dirumuskan. Bagi guru, setiap pemilihan metoda berarti menentukan jenis proses belajar mengajar mana yang dianggap efektif untuk mencapai tujuan yang telah dirumuskan. Hal ini juga sekaligus mengarahkan bagaimana guru mengorganisasikan kegiatan-kegiatan siswa dalam proses pembelajaran yang telah dipilihnya. Dengan demikian betapa pentingnya tujuan itu diperhatikan dan dirumuskan dalam setiap pembelajaran, agar pembelajaran itu benarbenar dapat mencapai tujuan sebagaiman yang tertuang dalam kurikulum.

Keberhasilan pelaksanaan pembelajaran ditentukan oleh kemampuan guru dalam mendesain pembelajaran, selain penguasaaan materi pelajaran itu sendiri. Kegiatan pembelajaran yang didesain dengan baik menyebabkan pembelajaran menjadi berkualitas. Seorang guru diharapkan mampu menyusun rencana pelaksanaan pembelajaran yang disesuaikan dengan tuntutan kurikulum, menyusun pertanyaan yang mendorong siswa untuk 
berpikir kritis dan analisis, dan terlebih penting adalah kemampuan guru dalam menyusun lembar kerja.

Oleh karena itu, pada artikel masalah yang diteliti adalah bagaimana kemampuan mahasiswa jurusan pendidikan matematika yang melakukan kegiatan praktik pengalaman lapangan (PPL) dalam mendesain pembelajaran yang berbasis kurikulum 2013 khususnya dalam menyusun rencana pelaksanaan pembelajaran dengan pendekatan saintifik.

\section{TEORI-TEORI BELAJAR}

Belajar meliputi segala perubahan baik berpikir, pengetahuan, informasi, kebiasaan, sikap apresiasi maupun pengertian. Ini berarti kegiatan belajar ditunjukan oleh adanya perubahan tingkah laku sebagai hasil pengalaman. Perubahan akibat proses belajar adalah karena adanya usaha dari individu dan perubahan tersebut berlangsung lama. Belajar merupakan kegiatan yang aktif, karena kegiatan belajar dilakukan dengan sengaja, sadar dan bertujuan.

Agar kegiatan belajar mencapai hasil yang optimal, maka diusahakan faktor penunjang seperti kondisi peserta didik yang baik, fasilitas dan lingkungan yang mendukung serta proses belajar mengajar yang tepat. Ada tiga kategori utama atau kerangka filosofis mengenai teori-teori belajar, yaitu: teori belajar behaviorisme, teori belajar kognitivisme, dan teori belajar konstruktivisme. Teori belajar behaviorisme hanya berfokus pada aspek objektif diamati pembelajaran. Teori kognitif melihat melampaui perilaku untuk menjelaskan pembelajaran berbasis otak. Pandangan konstruktivisme belajar sebagai sebuah proses di mana pelajar aktif membangun atau membangun ide-ide baru atau konsep.

a. Teori Belajar Behaviorisme

Teori behavioristik adalah sebuah teori yang dicetuskan oleh Gage dan Berliner tentang perubahan tingkah laku sebagai hasil dari pengalaman. Teori ini lalu berkembang menjadi aliran psikologi belajar yang berpengaruh terhadap arah pengembangan teori dan praktik pendidikan dan pembelajaran yang dikenal sebagai aliran behavioristik. Aliran ini menekankan pada terbentuknya perilaku yang tampak sebagai hasil belajar. Teori behavioristik dengan model hubungan stimulus-responnya, mendudukkan orang yang belajar sebagai individu yang pasif. Respon atau perilaku tertentu dengan menggunakan metode pelatihan atau pembiasaan semata. Munculnya 
perilaku akan semakin kuat bila diberikan penguatan dan akan menghilang bila dikenai hukuman.

b. Teori Belajar Kognitivisme

Teori belajar kognitif mulai berkembang pada abad terakhir sebagai protes terhadap teori perilaku yang yang telah berkembang sebelumnya. Model kognitif ini memiliki perspektif bahwa para peserta didik memproses infromasi dan pelajaran melalui upayanya mengorganisir, menyimpan, dan kemudian menemukan hubungan antara pengetahuan yang baru dengan pengetahuan yang telah ada. Model ini menekankan pada bagaimana informasi diproses. Peneliti yang mengembangkan teori kognitif ini adalah Ausubel, Bruner, dan Gagne. Dari ketiga peneliti ini, masing-masing memiliki penekanan yang berbeda. Ausubel menekankan pada apsek pengelolaan (organizer) yang memiliki pengaruh utama terhadap belajar.Bruner bekerja pada pengelompokkan atau penyediaan bentuk konsep sebagai suatu jawaban atas bagaimana peserta didik memperoleh informasi dari lingkungan.

c. Teori Belajar Konstruktivisme

Kontruksi berarti bersifat membangun, dalam konteks filsafat pendidikan dapat diartikan Konstruktivisme adalah suatu upaya membangun tata susunan hidup yang berbudaya modern. Konstruktivisme merupakan landasan berfikir (filosofi) pembelajaran konstektual yaitu bahwa pengetahuan dibangun oleh manusia sedikit demi sedikit, yang hasilnya diperluas melalui konteks yang terbatas. Pengetahuan bukanlah seperangkat fakta-fakta, konsep, atau kaidah yang siap untuk diambil dan diingat. Manusia harus mengkontruksi pengetahuan itu dan memberi makna melalui pengalaman nyata. Dengan teori konstruktivisme siswa dapat berfikir untuk menyelesaikan masalah, mencari idea dan membuat keputusan. Siswa akan lebih paham karena mereka terlibat langsung dalam mebina pengetahuan baru, mereka akan lebih paham dan mampu mengapliklasikannya dalam semua situasi. Selian itu siswa terlibat secara langsung dengan aktif, mereka akan ingat lebih lama semua konsep.

\section{PERENCANAAN/ DESAIN PEMBELAJARAN}

Perencanaan pembelajaran merupakan catatan-catatan hasil pemikiran awal seorang guru sebelum mengelola proses pembelajaran. Perencanaan pembelajaran merupakan persiapan mengajar yang berisi hal-hal yang perlu atau harus dilakukan oleh guru dan siswa dalam melaksanakan kegiatan 
pembeajaran yang antara lain meliputi unsur-unsur: pemilihan materi, metode, media, dan alat evaluasi.

Rencana pembelajaran dan silabus memiliki pengertian yang berbeda. Silabus memuat hal-hal yang perlu dilakukan oleh siswa untuk menuntaskan suatu kompetensi seeara utuh, artinya didalam suatu silabus adakalanya beberapa kompetensi yang sejalan akan disatukan sehingga perkiraan waktunya belum tahu pasti berapa pertemuan. Selain hal tersebut, silabus juga mengisyaratkan materi apa yang secara minimal perlu dikuasai oleh siswa untuk meneapai ketuntasan kompetensi.

Rencana pembelajaran adalah penggalan-penggalan kegiatan yang perlu dilakukan oleh guru untuk setiap pertemuan. Di dalamnya harus terlihat tindakan apa yang perlu dilakukan oleh guru untuk mencapai ketuntasan kompetensi serta tindakan selanjutnya setelah pertemuan selesai. Dengan kata lain rencana pembelajaran yang dibuat guru harus berdasarkan pada kompetensi inti dan kompetensi dasar.

Setiap kompetensi dirinci menjadi sub kompetensi atau kemampuan dasar yang selanjutnya merupakan arah pencapaian dan acuan dalam memilih materi dan pengalaman belajar siswa. Untuk mengetahui pencapaian kemampuan dasar tertentu diperlukan indikator pencapaian yang digunakan untuk mengembangkan alat pengujian.

Kegiatan belajar yang berlangsung di sekolah bersifat formal, disengaja, direncanakan, dengan bimbingan guru dan bantuan pendidik lainnya. Apa yang hendak dicapai dan dikuasai oleh siswa dituangkan dalam tujuan belajar, dipersiapkan bahan apa yang harus dipelajari, dipersiapkan juga metode pembelajaran, yaitu sesuai dengan cara siswa mempelajarinya, dan pada akhirnya dilakukan evaluasi untuk mengetahui kemajuan belajar siswa.

Pembelajaran berkenaan dengan kegiatan mengajar guru dan siswa belajar. Kegiatan pembelajaran ini merupakan suatu kegiatan dilakukan secara sadar berdasarkan pada aktivitas perencanaan, pelaksanaan dan evaluasi. Oleh karena itu setiap guru diharapkan mampu membuat perencanaan pembelajaran yang baik, kemudian melaksanakan pembelajaran sesuai dengan apa yang direncanakan dan diakhiri dengan kegiatan evaluasi untuk mengetahui pencapaian belajar siswa. Sebagaimana yang dikemukakan oleh Darmadi (2009) bahwa perencanaan persiapan mengajar sesungguhnya bertujuan mendorong guru agar lebih siap melakukan kegiatan pembelajaran dengan perencanaan yang matang. Oleh karena itu, setiap akan melakukan pembelajaran guru wajib melakukan persiapan pembelajaran. 


\section{DESAIN PERENCANAAN PEMBELAJARAN}

Desain pembelajaran sangat strategis, karena merupakan cara seorang guru sebagai ujung tombak perubahan melakukan usaha nyata untuk tercapainya komptensi. Dengan demikian keberhasilan proses pembelajaran merupakan jaminan suatu kualitas proses perubahan siswa/mahasiswa sebagai out-put. Lebih dari itu, keberhasilan perubahan kualitas pembelajaran suatu bangsa tergantung pada kesuksesan kualitas proses pembelajaran seorang guru.

Mengajar adalah membuat hasil belajar dapat tercapai (teaching as making larning possible). Ini dapat diterjemahkan secara kontekstual bahwa mengajar adalah usaha memanfaatkan berbagai strategi, mtode, dan teknik pembelajaran guna memungkinkan tercapainya kompetensi/ hasil belajar. Implikasi dari perubahan ini adalah semakin tinggi kualitas komptensi hasil belajar yang diproleh siswa atau mahasiswa, semakin tinggi pula tingkat kualitas kompetisi yang kelak mereka perankan dengan realitas.

Perencanaan adalah suatu cara yang memuaskan untuk membuat kegiatan dapat berjalan dengan baik, disertai dengan berbagai langkah yang antisipatif guna memperkecil kesenjangan yang terjadi sehingga kegiatan tersebut mencapai tujuan yang telah ditetapkan. Sedangkan yang dimaksud pembelajaran memiliki hakikat perencanaan atau perancangan (desain) sebagai upaya untuk membelajarkan siswa.

Dalam konteks pembelajaran, perencanaan dapat diartikan sebagai proses penyusunan materi pelajaran, penggunaan media, pendekatan dan metode pembelajaran, dan penilaian dalam suatu alokasi waktu yang akan dilaksanakan pada masa tertentu untuk mencapai tujuan yang telah ditentukan.

Perencanaan pembelajaran merupakan satu tahapan dalam proses pembelajaran yang sangat bergantung kepada kompetensi keguruan seorang guru. Guru yang baik berusaha sedapat mungkin agar berhasil. Salah satu faktor yang bisa membawa keberhasilan itu adalah sebelum masuk ke dalam kelas, guru senantiasa membuat perencanaan pembelajaran sebelum pelaksanaan pembelajaran berlangsung.

Desain strategi pembelajaran merupakan suatu elemen dari empat unsur utama dari sebuah desain pembelajaran, yaitu desain materi (content design), desain komptensi (competency learning objectives design), desain 
metode/strategi/teknik pembelajaran (instructional strategies design), dan desain evaluasi (evaluation design).

Desain pembelajaran sangat strategis, karena merupakan cara seorang guru sebagai ujung tombak perubahan melakukan usaha nyata untuk tercapainya komptensi. Dengan demikian keberhasilan proses pembelajaran merupakan jaminan suatu kualitas proses perubahan siswa/mahasiswa sebagai out-put. Lebih dari itu, keberhasilan perubahan kualitas pembelajaran suatu bangsa tergantung pada kesuksesan kualitas proses pembelajaran seorang guru.

Mengajar adalah membuat hasil belajar dapat tercapai (teaching as making larning possible). Ini dapat diterjemahkan secara kontekstual bahwa mengajar adalah usaha memanfaatkan berbagai strategi, mtode, dan teknik pembelajaran guna memungkinkan tercapainya kompetensi /hasil belajar. Implikasi dari perubahan ini adalah semakin tinggi kualitas komptensi hasil belajar yang diproleh siswa atau mahasiswa, semakin tinggi pula tingkat kualitas kompetisi yang kelak mereka perankan dengan realitas.

Dalam konteks pembelajaran, perencanaan dapat diartikan sebagai proses penyusunan materi pelajaran, penggunaan media, pendekatan dan metode pembelajaran, dan penilaian dalam suatu alokasi waktu yang akan dilaksanakan pada masa tertentu untuk mencapai tujuan yang telah ditentukan.

\section{PENDEKATAN SAINTIFIK DALAM PEMBELAJARAN}

Pendekatan pembelajaran yang diterakan pada kurikulum 2013 dikenal dengan istilah pendekatan saintifik. Kurikulum 2013 mengembangkan dua model proses pembelajaran yaitu proses pembelajaran langsung dan proses pembelajaran tidak langsung. Proses pembelajaran langsung adalah proses pendidikan di mana peserta didik mengembangkan pengetahuan, kemampuan berpikir dan keterampilan psikomotorik melalui interaksi langsung dengan sumber belajaryang dirancang dalam silabus dan RPP berupa kegiatan-kegiatan pembelajaran. Dalam pembelajaran langsung tersebut peserta didik melakukan kegiatan belajar mengamati, menanya, mengumpulkan informasi, mengasosiasi atau menganalisis, dan mengkomunikasikan apa yang sudah ditemukannya dalam kegiatan analisis. Proses pembelajaran langsung menghasilkan pengetahuan dan keterampilan langsung atau yang disebut dengan instructional effect. 
Pembelajaran tidak langsung adalah proses pendidikan yang terjadi selama proses pembelajaran langsung tetapi tidak dirancang dalam kegiatan khusus. Pembelajaran tidak langsung berkenaan dengan pengembangan nilai dan sikap. Berbeda dengan pengetahuan tentang nilai dan sikap yang dilakukan dalam proses pembelajaran langsung oleh mata pelajaran tertentu, pengembangan sikap sebagai proses pengembangan moral dan perilaku dilakukan oleh seluruh mata pelajaran dan dalam setiap kegiatan yang terjadi di kelas, sekolah, dan masyarakat.

Proses pembelajaran Kurikulum 2013, semua kegiatan yang terjadi selama belajar di sekolah dan di luar dalam kegiatan kokurikuler dan ekstrakurikuler terjadi proses pembelajaran untuk mengembangkan moral dan perilaku yang terkait dengan sikap. Baik pembelajaran langsung maupun pembelajaran tidak langsung terjadi secara terintegrasi dan tidak terpisah. Pembelajaran langsung berkenaan dengan pembelajaran yang menyangkut KD yang dikembangkan dari KI-3 dan KI-4. Keduanya, dikembangkan secara bersamaan dalam suatu proses pembelajaran dan menjadi wahana untuk mengembangkan KD pada KI-1 dan KI-2. Pembelajaran tidak langsung berkenaan dengan pembelajaran yang menyangkut KD yang dikembangkan dari KI-1 dan KI-2.

Proses pembelajaran terdiri atas lima pengalaman belajar pokok yaitu:
a. mengamati;
b. menanya;
c. mengumpulkan informasi;
d. mengasosiasi; dan
e. mengkomunikasikan.

\section{METODE PENELITIAN}

Metode penelitian yang digunakan penelitian kualitatif dengan model studi kasus pada mahasiswa jurusan pendidikan matematika yang sementara melakukan praktik pengalaman lapangan (PPL). Penelitian yang dilakukan difokuskan pada mahasiswa jurusan pendidikan matematika Fakultas Tarbiyah dan Keguruan UIN Alauddin Makassar yang sementara melakukan kegiatan PPL SMP/MTs. Data penelitian ini diperoleh dari produk Rencana Pelaksanaan Pembelajaran (RPP) atau skenario pembelajaran yang dibuat oleh mahasiswa melakukan PPL.

Data yang terkumpul selanjutnya akan dianalisis dengan mendeskripsikan Rencana Pelaksanaan Pembelajaran (RPP) atau skenario 
pembelajaran yang dibuat oleh mahasiswa yang melakukan PPL di SMP/MTs. Analisis mendalam dilakukan secara kualitatif dengan dengan berpedoman pada Permendikbud No 58 tahun 2014 tentang Kurikulum 2013 yang memuat pendekatan saintifik dengan aktivitas mengamati, menanya, menvoba, menalar, dan mengomunikaskan.

\section{HASIL PENELITIAN}

Pelaksanaan pembelajaran didahului dengan penyiapan rencana pelaksanaan pembelajaran (RPP) yang dikembangkan oleh guru baik secara individual maupun kelompok yang mengacu pada Silabus. Strategi penilaian disiapkan untuk memfasilitasi guru dalam mengembangkan pendekatan, teknik dan instrumen penilaian hasil belajar dengan pendekatan penilaian otentik yang memungkinkan para pendidik menerapkan program remedial bagi peserta didik yang tergolong pebelajar lambat dan program pengayaan bagi peserta didik yang termasuk kategori pebelajar cepat.

Pada proses pembelajaran langsung di mana peserta didik mengembangkan pengetahuan, kemampuan berpikir dan keterampilan psikomotorik melalui interaksi langsung dengan sumber belajar yang dirancang dalam silabus dan RPP berupa kegiatan-kegiatan pembelajaran. Dalam pembelajaran langsung tersebut peserta didik melakukan kegiatan belajar mengamati kejadian, peristwa, situasi, pola, fenomena yang terkait dengan matematika; menanya atau mempertanyakan mengapa atau bagaimana fenomena bisa terjadi; mengumpulkan atau menggali informasi melalui mencoba, percobaan, mengkaji, mendiskusikan untuk mendalami konsep yang terkait dengan fenomena tersebut; serta melakukan asosiasi atau menganalisis secara kritis dalam menjelaskan keterkaitan antar konsep dan menggunakan, memanfaatkan dan memilih prosedur/algoritma yang sesuai, menyusun penalaran dan generalisasi, dan mengkomunikasikan apa yang sudah ditemukannya dalam kegiatan analisis. Proses pembelajaran langsung menghasilkan pengetahuan dan keterampilan langsung atau yang disebut dengan instructional effect.

Pada Pembelajaran tidak langsung yang terjadi selama proses pembelajaran langsung tetapi tidak dirancang dalam kegiatan khusus. Pembelajaran tidak langsung berkenaan dengan pengembangan nilai dan sikap. Berbeda dengan pengetahuan tentang nilai dan sikap yang dilakukan dalam proses pembelajaran langsung oleh mata pelajaran tertentu, pengembangan sikap sebagai proses pengembangan moral dan perilaku 
dilakukan oleh seluruh mata pelajaran dan dalam setiap kegiatan yang terjadi di kelas, sekolah, dan masyarakat.

Oleh karena itu, dalam proses pembelajaran Kurikulum 2013, semua kegiatan yang terjadi selama belajar di sekolah dan di luar dalam kegiatan kokurikuler dan ekstrakurikuler terjadi proses pembelajaran untuk mengembangkan moral dan perilaku yang terkait dengan sikap.

Baik pembelajaran langsung maupun pembelajaran tidak langsung terjadi secara terintegrasi dan tidak terpisah. Pembelajaran langsung berkenaan dengan pembelajaran yang menyangkut KD yang dikembangkan dari KI-3 dan KI-4. Keduanya, dikembangkan secara bersamaan dalam suatu proses pembelajaran dan menjadi wahana untuk mengembangkan KD pada KI-1 dan KI-2. Pembelajaran tidak langsung berkenaan dengan pembelajaran yang menyangkut KD yang dikembangkan dari KI-1 dan KI-2.

Kelima pembelajaran pokok tersebut dapat dirinci dalam berbagai kegiatan belajar sebagaimana tercantum dalam tabel berikut:

Tabel 1. Deskripsi Langkah Pembelajaran*)

\begin{tabular}{|c|c|c|}
\hline $\begin{array}{c}\text { Langkah } \\
\text { Pembelajaran }\end{array}$ & Deskripsi Kegiatan & Bentuk Hasil Belajar \\
\hline Mengamati (observing) & $\begin{array}{l}\text { mengamati dengan indra } \\
\text { (membaca, mendengar, } \\
\text { menyimak, melihat, } \\
\text { menonton, dan sebagainya) } \\
\text { dengan atau tanpa alat }\end{array}$ & $\begin{array}{l}\text { perhatian pada waktu } \\
\text { mengamati suatu } \\
\text { objek/membaca suatu } \\
\text { tulisan/mendengar suatu } \\
\text { penjelasan, catatan yang } \\
\text { dibuat tentang yang diamati, } \\
\text { kesabaran, waktu (on task) } \\
\text { yang digunakan untuk } \\
\text { mengamati }\end{array}$ \\
\hline Menanya (questioning) & $\begin{array}{l}\text { membuat dan mengajukan } \\
\text { pertanyaan, tanya jawab, } \\
\text { berdiskusi tentang informasi } \\
\text { yang belum dipahami, } \\
\text { informasi tambahan yang } \\
\text { ingin diketahui, atau sebagai } \\
\text { klarifikasi. }\end{array}$ & $\begin{array}{l}\text { jenis, kualitas, dan jumlah } \\
\text { pertanyaan yang diajukan } \\
\text { peserta didik (pertanyaan } \\
\text { faktual, konseptual, } \\
\text { prosedural, dan hipotetik) }\end{array}$ \\
\hline $\begin{array}{l}\text { Mengumpulkan } \\
\text { Informasi } \\
\text { (experimenting) }\end{array}$ & $\begin{array}{l}\text { mengeksplorasi, mencoba, } \\
\text { berdiskusi, mendemonstrasi- } \\
\text { kan, meniru bentuk/gerak, } \\
\text { melakukan eksperimen, }\end{array}$ & $\begin{array}{l}\text { jumlah dan kualitas sumber } \\
\text { yang dikaji/digunakan, } \\
\text { kelengkapan informasi, } \\
\text { validitas informasi yang }\end{array}$ \\
\hline
\end{tabular}




\begin{tabular}{|c|c|c|}
\hline & $\begin{array}{l}\text { membaca sumber lain selain } \\
\text { buku teks, mengumpulkan } \\
\text { data dari nara sumber melalui } \\
\text { angket, wawancara, dan } \\
\text { memodifikasi/ } \\
\text { menambahi/mengembangkan }\end{array}$ & $\begin{array}{l}\text { dikumpulkan, dan } \\
\text { instrumen/alat yang } \\
\text { digunakan untuk } \\
\text { mengumpulkan data. }\end{array}$ \\
\hline $\begin{array}{l}\text { Menalar/Mengasosiasi } \\
\text { (associating) }\end{array}$ & $\begin{array}{l}\text { mengolah informasi yang } \\
\text { sudah dikumpulkan, } \\
\text { menganalisis data dalam } \\
\text { bentuk membuat kategori, } \\
\text { mengasosiasi atau } \\
\text { menghubungkan } \\
\text { fenomena/informasi yang } \\
\text { terkait dalam rangka } \\
\text { menemukan suatu pola, dan } \\
\text { menyimpulkan. }\end{array}$ & $\begin{array}{l}\text { mengembangkan interpretasi, } \\
\text { argumentasi dan kesimpulan } \\
\text { mengenai keterkaitan } \\
\text { informasi dari dua } \\
\text { fakta/konsep, interpretasi } \\
\text { argumentasi dan kesimpulan } \\
\text { mengenai keterkaitan lebih } \\
\text { dari dua fakta/konsep/teori, } \\
\text { mensintesis dan argumentasi } \\
\text { serta kesimpulan keterkaitan } \\
\text { antar berbagai jenis fakta- } \\
\text { fakta/konsep/teori/pendapat; } \\
\text { mengembangkan interpretasi, } \\
\text { struktur baru,argumentasi, } \\
\text { dan kesimpulan yang } \\
\text { menunjukkan hubungan } \\
\text { fakta/konsep/teori dari dua } \\
\text { sumber atau lebih yang tidak } \\
\text { bertentangan; } \\
\text { mengembangkan interpretasi, } \\
\text { struktur baru, argumentasi } \\
\text { dan kesimpulan dari } \\
\text { konsep/teori/pendapat yang } \\
\text { berbeda dari berbagai jenis } \\
\text { sumber. }\end{array}$ \\
\hline $\begin{array}{l}\text { Mengomunikasi-kan } \\
\text { (communicating) }\end{array}$ & $\begin{array}{l}\text { menyajikan laporan } \\
\text { dalam bentuk bagan, } \\
\text { diagram, atau grafik; } \\
\text { menyusun laporan } \\
\text { tertulis; dan } \\
\text { menyajikan laporan } \\
\text { meliputi proses, hasil, } \\
\text { dan kesimpulan secara } \\
\text { lisan }\end{array}$ & $\begin{array}{l}\text { menyajikan hasil kajian (dari } \\
\text { mengamati sampai menalar) } \\
\text { dalambentuk tulisan, grafis, } \\
\text { media elektronik, multi media } \\
\text { dan lain-lain }\end{array}$ \\
\hline
\end{tabular}


Berdasarkan deskripsi langkah pembelajaran dengan pendekatan saintifik, maka skenario pembelajaran yang telah dirancang oleh mahasiswa PPL jurusan pendidikan matematika dapat disajikan berikut ini:

a. Mengamati

Sebagaimana yang tercantum pada tabel 1 bahwa kegiatan pembelajaran yang terkait dengan aktivitas mengamati adalah mengamati dengan indra (membaca, mendengar, menyimak, melihat, menonton, dan sebagainya) dengan atau tanpa alat.

Pada skenario pembelajaran yang telah disusun oleh mahasiswa tampak bahwa kegiatan mengamati pada skenario yang disusun sudah mulai terlihat. Hal ini dapat dilihat dari beberapa aktivitas pengamatan yang telah dirancang oleh mahasiswa yaitu:

\section{Skenario Pembelajaran R1:}

Kegiatan diawali dengan siswa diminta mengamati masalah yang disajikan guru dengan power point.

Kegiatan mengamati pada langkah ini masih bersifat umum. Sebagaimana disajikan sebelymnya bahwa aktivitas mengamati tersebut, belum tampak dengan jelas masalah yang disajikan apakah masalah tersebut kontekstual atau tidak. Hal ini menjadi penting karena siswa diharapkan mampu menemukan kaitan antara materi yang dipelajari dengan masalah kontekstual. Selain itu diharapkan juga agar siswa mampu mengamati dengan saksama permasalahan yang diberikan sehingga mampu mengkonstruksi sesuatu dari aktivitas amatan tersebut.

\section{Skenario Pembelajaran R2:}

- Siswa mendengarkan dan memperhatikan materi kaidah pencacahan yang dipaparkan oleh guru

- Siswa diminta untuk mengamati contoh soal dan cara penyelesaiannya pada buku paket.

Kegiatan mengamati ada langkah ini masih berada pada konteks amatan level mendengar. Hal ini akan berakibat pada siswa kondisi siswa 
yang kurang aktif. Sedangkan aktivitas mengamati pada pendekatan saintifik siswa diharapkan mampu mengaktifkan siswa dalam aktivitas pembelajaran.

\section{Skenario Pembelajaran R3:}

- Siswa memperhatikan gambar hiperbola pada buku yang telah dibagikan

- Siswa membaca dari berbagai sumber yang berkaitan dengan hiperbola

Langkah pembelajaran yang disajikan di atas masih menunjukkan adanya unsur abstraksi dari konsep hiperbola. Oleh karenanya ketika siswa diperlihatkan gambar seperti hiperbola, maka siswa masih memungkinkan munculnya pemahaman yang konse yang abstrak.

\section{Skenario Pembelajaran R4:}

Masing-masing kelompok mengamati dan mencermati masalah kontekstual yang terkait operasi hitung campuran bilangan bulat

Aktivitas mengamati pada kegiatan di atas pada dasarnya sudah memenuhi prinsip mengamati pada pendekatan saintifik. Akana tetapi pada skenari pembelajaran yang disajikan justru masalah kontekstual tersebut tidak tampak atau tidak muncul.

Berdasarkan analisis beberapa aktivitas pembelajaran terkait dengan aktivitas mengamati pada pendekatan saintifik dapat dikatakan bahwa para mahasiswa sudah mulai mampu memunculkan beberapa kegiatan atau aktivitas yang mengarahkan siswa untuk mengamati suatu objek. Akan tetapi operasional objek yang akan diamati tersebut sebaiknya tergambarkan dalam bentuk tayangan sebagai suatu stimulus dalam memahami konsep atau mencapai tujuan pembelajaran yang ingin dicapai.

b. Menanya

Deskripsi kegiatan yang terkait dengan aktivitass bertanya adalah Membuat dan mengajukan pertanyaan, tanya jawab, berdiskusi tentang informasi yang belum dipahami, informasi tambahan yang ingin diketahui, atau sebagai klarifikasi. 


\section{Skenario Pembelajaran R1:}

Siswa diberi kesempatan menanyakan hal-hal yang menarik dan belum diketahui tentang masalah yang dipecahkan

\section{Skenario Pembelajaran R2:}

Siswa menanggapi permasalahan-permasalahan sederhana yang mengarah pada konsep peluang

\section{Skenario Pembelajaran R3:}

Guru mengarahkan siswa untuk menanyakan hal-hal yang terkait dengan hiperbola. Misalnya apa perbedaan titik fokus dan direktris dan bagaimana kaitannya dengan hiperbola?

\section{Skenario Pembelajaran R4:}

Dari hasil pengamatan yang dilakukan, secara berkelompok siswa menyusun daftar pertanyaan yang muncul untuk mengembangkan materi ajar.

Aktivias menanya dalam konteks pembelajaran berbasis kurikulum 2013 ditekankan pada munculnya kesadaran siswa untuk memahami sesuatu setelah melalui proses pengamatan yang kuat. Pertanyaan yang muncul bisa ditujukan kepada guru, siswa, atau kepada diri sendiri. Namun demikian berdasarkan skenario pembelajaran yang dibuat oleh mahasiswa PPL jurusan pendidikan matematika masih ada kecenderungan bahwa pertanyaan tersebut muncul bukan karena kesadaran siswa untuk mengetahui sesuatu. Akan tetapi pertanyaan yang muncul karena masih adanya arahan dari guru.

c. Mengumpulkan Informasi

Skenario pembelajaran yang disusun oleh mahasiswa PPL untuk aktivitas mengumpulkan informasi disajikan sebagai berikut: 


\section{Skenario Pembelajaran R1:}

Setiap kelompok mempelajari sifat 5.1 dan 5.2

\section{Skenario Pembelajaran R2:}

Siswa diminta untuk mengamati contoh dan cara penyelesaiannya pada buku paket

\section{Skenario Pembelajaran R3:}

Guru membagi siswa ke dalam beberapa kelompok

Tiap kelompok mendapat tugas untuk mengerjakan LKS yang telah dibagikan

\section{Skenario Pembelajaran R4:}

Siswa bereksplorasi untuk mengetahui cara menghitung operasi campuran dan mengerjakan soal latihan dengan memperhatikan sifat operasi hitung campunran bilangan bulat

Aktivitas mengumpulkan informasi berupa mengeksplorasi, mencoba, berdiskusi, mendemonstrasikan, meniru bentuk/gerak, melakukan eksperimen, membaca sumber lain selain buku teks, mengumpulkan data dari nara sumber melalui angket, wawancara, dan memodifikasi/ menambahi/mengembangkan.

Aktivitas mengumpulkan informasi pada skenario pembelajaran yang disusun oleh mahasiswa PPL masih bersifat normatif, meskipun sudah ada kecenderungan untuk mencoba melibatkan siswa secara langsung memahami permasalahan dan konsep yang diberikan.

d. Menalar

Kegiatan menalar dapat berupa mengolah informasi yang sudah dikumpulkan, menganalisis data dalam bentuk membuat kategori, mengasosiasi atau menghubungkan fenomena/informasi yang terkait dalam rangka menemukan suatu pola, dan menyimpulkan.

Skenario pembelajaran yang disusun oleh mahasiswa PPL yang berkaitan dengan aktivitas menalar dapat disajikan sebagai berikut: 


\section{Skenario Pembelajaran R1:}

Setiap siswa diberi kesempatan memaparkan hasil temuan yang di dapat dari masalah-masalah yang telah diselesaikan.

Siswa diminta menemukan suatu kesimpulan apa yang mereka peroleh berdasarkan penyelesaian masalahh yang telah diberikan

\section{Skenario Pembelajaran R2:}

Guru mengajukan beberapa soal mengenai penyusunan dan penggunaan aturan perkalian permutasi dan kombinasi

\section{Skenario Pembelajaran R3:}

Siswa menyelesaikan tugas yang berkaitan dengan hiperbola yang berpuncak di $O$ $(0,0)$ dan $(h, k)$ untuk menentukan garis direktris, titik fokus dan menggambar grafik hiperbola.

\section{Skenario Pembelajaran R4:}

Melalui hasil eksplorasi setiap kelompok membuat kesimpulan sementara tentang operasi hitung campuran bilangan bulat

Berdasarkan skenario pembelajaran yang telah disusun oleh mahasiswa PPL, tampak bahwa aktivias menalar pada kegiatan pembelajaran yang sudah mulai tanpak. Hal ini dapat dilihat dari aktivitas seperti yang disajikan pada skenario pembelajaran R1 yaitu Siswa diminta menemukan suatu kesimpulan apa yang mereka peroleh berdasarkan penyelesaian masalahh yang telah diberikan. Siswa mampu menyimpulkan sesuatu ketika ada proses menalar atau menghubungkan antara satu fakta atau prinsip yang disesuaikan dengan tujuan pembelajaran yang ingin dicapai.

Hal lain yang terkait dengan aktivitass menalar adalah seperti tampak pada aktivita R4 yaitu Melalui hasl eksplorasi setiap kelompok membuat kesimpulan sementara tentang operasi hitung campuran bilangan bulat.

Berdasarkan skenario yang disusun oleh mahasiswa PPL dapat didkatakan bahwa aktivitas menalar dalam kegiatan pembelajaran mulai tampak. 
e. Mengomunikasikan

Kegiatan mengomunikaskan pada kegiatan pembelajaran dengan pendekatan saintifik dapat dilakukan dalam berbagai bentuk diantaranya menyajikan laporan dalam bentuk bagan, diagram, atau grafik; menyusun laporan tertulis; dan menyajikan laporan meliputi proses, hasil, dan kesimpulan secara lisan.

Skenario pembelajaran yang memuat aktivitas mengomunikasikan yang telah disusun oleh mahasiswa PPL dapat disajikan sebagai berikut:

\section{Skenario Pembelajaran R1:}

Beberapa siswa mempresentasikan hasil penyelesaian masalah di depan kelas. Siswa lain memberii tanggapan. Guru memberi umpan balik.

\section{Skenario Pembelajaran R2:}

Guru menunjuk siswa secara acak untuk menuliskan jawabannya di papan tulis.

\section{Skenario Pembelajaran R3:}

Beberapa kelompok diskusi diminta untuk mempresentasikan hasil diskusinya ke depan kelas. Sementara kelompok lain menanggapi dan menyempurnakan apa yang dipresentasikan.

Dengan tanyan jawab guru mengkonfirmasi mengenai jawaban dari lathan tersebut kemudian memberi penguatan terhadap usaha belajar yang dilakukan tiap kelompok.

\section{Skenario Pembelajaran R4:}

Secara random dipilih beberapa kelompok untuk menyampaikan hasil diskusi mereka, sementara kelompok lain mengkritisi.

Berdasarkan skenario di atas, maka dapat dikatakan bahwa aktivitas mengomunikasikan pada kegiatan pembelajaran secara umum dapat disusun oleh mahasiswa PPL dengan baik. Hal ini tampak pada sekario pembelajaran di atas. Akan tetapi bentuk mengomunikasikan hasil pembelajaran masih bersifat pada kegiatan mempresentasikan hasil kerja di depan kelas.

Salah satu aspek yang menjadi penekanan dalam pembelajaran yang dilakukan dikelas adalah mengaktifkan siswa selama proses pembelajaran. Siswa yang aktif yang dimaksudkan adalah siswa berperan atau memiliki 
peran pada setiap aktivitas pembelajaran mulai dari awal sampai pada akhir pembelajaran.

Pendektan saintifik yang penekanannya pada aktivitas mengamati, menanya, mencoba/mengolah informasi, menalar dan mengomunikasikan yang lebih dikenal dengan istilah 5M menjadi salah satu pilar dalam konteks implementasi kurikulum 2013. Aktivitas 5M ini penekanannya pada aktivitas atau keterlibatan siswa dalam setiap pembelajaran.

Hasil analisis skenario pembelajaran yang disusun oleh mahasiswa PPL jurusan pendidikan matematika masih menunjukkan beberapa hal yang masih kurang diantaranya pada aktivitas mengamati. Aktivitas mengamati yang dilakukan oleh mahasiswa masih pada konteks mengamati dengan menggunakan intra mata dan belum memaksimalkan indra yang lainnya.

Pengamatan yang kuat dan mendalam akan memunculkan timbulnya pertanyaan yang secara sadar muncul dari siswa. Akan tetapi pada skenario pembelajaran yang disusun oleh mahasiswa aktivitas bertanya masih didominasi oleh guru. Sedangkan aktivitas mencoba, menalar, dan mengomunikasikan sudah mulai tampak pada aktivitas pembelajaran.

\section{SIMPULAN}

Berdasarkan hasil analisis pada skenario pembelajaran yang telah disusun oleh mahasiswa PPL jurusan pendidikan matematika, maka dapat disimpulkan bahwa mahasiswa PPL jurusan pendidikan matematika dalam menyusun skenario pembelajaran dengan pendekatan saintifik masih kurang khususnya pada aktivitas mengamati dan menanya. Hasil penelitian ini menyarankan beberapa hal yaitu perlunya pengenalan lebih mendalam tetang pendekatan saintifik dalam pembelajaran.Perunya dosen memberikan materi tambahan terkait dengan kurikulum 2013. Perlunya dosen melakukan pembimbingan mendalam kepada mahasiswa khususnya dalam menyusun rencana pelaksanaan pembelajaran.

\section{DAFTAR PUSTAKA}

Arikunto, S. (2006). Prosedur penelitian pendekatan praktek. Yogyakarta: Rineka Cipta.

Aunurrahman. (2009). Belajar dan pembelajaran. Cet. II. Bandung: Alfabeta.

Barry, K., \& Len, K. (2002). Beginning teaching, International Edition, New South Wales: Social Science Press. 
Biggs, J.B., \& Collis, K.F. (1982). Evaluating the quality of learning: the solo taxonomy. New York: Academic Press

Blok, J. H. (1979). Mastery learning :theory and practice. New York: Holt, Rinehart and Winston, Inc.

Bloom, B. S. ed. et al. (1956). Taxonomy of educational objectives: Handbook 1, Cognitive Domain. New York: David McKay.

Bluestein, J., et all. (2013). Classroom management. diterjemahkan oleh Siti Mahyuni dengan judul Manajemen kelas. Cet. I. Jakarta: Indeks.

Danim, S. (2002). Inovasi Pendidikan dalam upaya peningkatan profesinalisme tenaga kependidikan. Bandung: Pustaka Setia.

Darmadi, H. Kemampuan dasar mengajar. (2009). Cet, I. Bandung: Alfabeta.

Depdiknas. (2006). Pengembangan pembelajaran yang efektif. Direktorat Pembinaan SMP, Dirjen Dikdasmen.

Dimyati \& Mudjiono. (1999). Belajar dan pembelajaran. Yakarta: Rineka Cipta.

Eggen, P., \& Don, K. (1994). Educational psychology: classroom connections, New York: Macmillan College.

Good, T., \& Jere, E. B. (2003). Looking in classrooms. Cet, VI. Boston: Allyn and Bacon.

Harjanto. (2010). Perencanaan pengajaran: komponen MKDK. Cet. VII. Jakarta: Rineka Cipta.

Hamalik, O. (2007). Proses belajar mengajar. Cet. VI. Jakarta: Bumi Aksara.

Harmer, J. (1998). How to teach english. Cet. I; Harlow-England: Addison Wesley Longman.

Ismail. (2008). Strategi pembelajaran agama islam berbasis PAIKEM. Semarang: Elsis.

Johnson, E.B. (2007). Contextual teaching and learning. California: Corwin Press.Inc. 
Joyce, B., \& Marsha, W. (1986). Models of teaching. New Jersey: Prentice-Hall International.

Madjid, A. (2005). Perencanaan pembelajaran: mengembangkan kompetensi guru. Bandung: PT Remaja Rosda Karya.

Matsumo, D. (2000). Culture and psychology people around the world. Stamford: Wodsworth Thomson Learning.

Moedjono, \& Dimyanti, M. (1993). Strategi belajar mengajar. Jakarta: Departemen P \& K Dikti Proyek Pembinaan Tenaga Kependidikan.

Mukminan, dkk. (1998). Belajar dan pembelajaran. Pusat Pengembangan Pendidikan Profesi Guru. IKIP Yogyakarta.

Nana, S. (1990). Teori-teori belajar untuk pengajaran, FEUI: Jakarta.

Nurhadi, B. Y., \& Agus, G. S. (2004). Pembelajaran kontekstual (CTL) dan penerapannya dalam KBK. Malang: Universitas Negeri Malang.

Sagala, S. (2005). Konsep dan makna pembelajaran, Cet. II. Bandung: Alfabeta.

Sa'ud, U. S., \& Abin, S. M. (2007). Perencanaan pendidikan. Cet. Ill. Bandung: Remaja Rosdakarya.

Silberman, M. L. (2006). Active learning: 101 cara pembelajaran siswa aktif. Bandung: Nuansa.

Slamet. (1991). Belajar dan faktor-faktor yang mempengaruhi. Jakarta: Rineka Cipta

Slavin, R. E. (2005). Cooperative learning: theory, research and practice. London: Allymand Bacon.

Sujana, N. (2005). Pembinaan dan pengembangan kurikulum di sekolah. Cet. V. Bandung: Sinar Baru Algesindo, 2005.

Sudjana, D. S. (2004). Manajemen program pendidikan untuk pendidikan non formal dan pengembangan sumber daya manusia. Bandung: Falah Production.

Suherman, E., \& Yaya, S. K. (1990). Petunjuk praktis untuk melaksanakan evaluasi pendidikan matematika. Bandung: Wijaya Kusuman. 
Suherman, E., \& Winataputra, U. S. (1992). Strategi BELAJAR MENGAJAR MATEMatika. Depdikbud. Jakarta.

Uno, B. H. (2008). Perencanaan pembelajaran, Cet. III. Jakarta: Bumi Aksara.

Wright, T.Roles of Teachers and learners. (1987). Oxford: Oxford University Press. 